\title{
Socio- Demographic Characteristics and Impact of Support Services On Performance of Technical Entrepreneurs in South-Western Nigeria
}

\author{
Adeyemo, F.S. \\ Department of Business Administration \\ Caleb University \\ Imota, Lagos State, Nigeria \\ E-mail: feliciaadeyemo@yahoo.com \\ Ilori, M.O. \\ African Institute for Science Policy and Innovations \\ Obafemi Awolowo University, Ile-Ife, Nigeria \\ Adeyemo, O.E. \\ Department of Computer Science \\ Caleb University \\ Imota, Lagos State, Nigeria
}

\begin{abstract}
This study examined the socio-demographic characteristics and the impact of support services on the performance of technical entrepreneurs in south-western Nigeria. The study considered a total of 264 technical entrepreneurs confirmed through 14 institutions to have received one support service or the other from these institutions in the course of their entrepreneurial activities. . Analyses of data gathered through well administered questionnaires showed that gender participation in entrepreneurship is $55.7 \%$ and $44.3 \%$ for male and female respectively. About $57.6 \%$ of the respondents were in age group of $31-45$ years while the mean age is 39 year and standard deviation is 19 years. The result further showed that $75.4 \%$ were married, $97.7 \%$ were Nigerians, $67.8 \%$ had post-secondary education and $34.8 \%$ were specialised in vocational and technical education. Most (78.0\%) were owners of their businesses while $43.9 \%$ had been in business within $5-10$ years and $3.8 \%$ had been in business within 21 - 25 years. The mean year of experience was about 9 years while the standard deviation is 5 years. Also using ANOVA, the analysis showed that the technical support services provided had significant impact on production output $(\mathrm{F}=3.74$, $\mathrm{p}<0.05)$ and sales turnover $(\mathrm{F}=3.00, \mathrm{p}<0.05)$ of the entrepreneurs. Financial support services significantly impacted production output $(\mathrm{F}=2.29, \mathrm{p}<0.0010)$ and sales turnover $(\mathrm{F}=2.53, \mathrm{p}<0.05)$. Information services had significant impact on reduction in maintenance costs $(\mathrm{F}=2.580, \mathrm{p}<0.05)$ and product quality $(\mathrm{F}=3.37$, $\mathrm{p}<0.05)$ while human resource development had significant impact on profitability $(\mathrm{F}=2.68, \mathrm{p}<0.05)$ and product quality $(\mathrm{F}=5.65, \mathrm{p}<0.01)$. It can be concluded that the support services received by technical entrepreneurs significantly impacted the performance of the entrepreneurs.
\end{abstract}

Keywords: Technical Entrepreneur, Impact, Support Services, Performance

Journal Reference Format:

Adeyemo, F.S., Ilori, M.O. \& Adeyemo, O.E. (2017): Socio- Demographic Characteristics and Impact of Support Services On

Performance of Technical Entrepreneurs in South-Western Nigeria. Humanities, Management, Arts, Education \& the Social

Sciences Journal. Vol. 5. No. 4, Pp 77-85. Article DOI: dx.doi.org/10.22624/AIMS/HUMANITIES/V5N1P9

Available online at www.humanitiesjournal.org 


\section{INTRODUCTION}

Entrepreneurship is a major catalyst that drives the economy of most nations (Say, 1824; Schoof, 2006). It is also the engine that engenders the introduction of new approaches in business and market place (Wood, 2005; Olatunji, 2010). Entrepreneurship guarantees job and wealth creation as well as economic returns from diverse forms of activities. It is the vehicle ridden by innovation which is the application of knowledge in production activities (Ubom, 2003). Entrepreneurs are considered as "champions" especially for converting products and services that ultimately create wealth and reduce unemployment. Hence, today entrepreneurship is an agent of job creation and an approach for integrating the youth into the labour market in many advanced countries (Ubom, 2003). According to Ronstadt (1996) entrepreneurship is the dynamic process of incremental wealth creation by individuals who assume the major risks in terms of equity, time, and/or career commitment of providing valuable product and/or technical service. The product or technical service may not be new or unique, but value is usually infused by the entrepreneur through the allocation of required skills and resources.

\section{TECHNICAL ENTREPRENEURSHIP}

Technical entrepreneurship deals with the manufacturing of products and/or provision of technical services for wealth creation building ventures focusing on technology. Technical entrepreneurship can be based on creation of a new company, expansion of an existing one, commercialization of a new product or process from scientific research or technology development (Ilori, 2010). According to Schumpeter (1939), there are five basic forms of technical entrepreneurship, the introduction of new goods in the market is the first of these. By new product, it means something that has been invented and has never been available in the market before. In simple terms, whenever a new invention is made, it is seen as an act of entrepreneurship. The second is the introduction of a new method of production by new method, it is assumed that the method that is effective and is able to improve on an existing production method. The third form of technical entrepreneurship is the opening of a new market. Whenever such resources are provided that enables the population to benefit, e.g. economic, education among others., it establishes a new opportunity that is known as a new market for using that particular resource.

The fourth form is the conquest of a new source which allows the industry to increase its productivity. This new source can be in many forms including the discovery of a natural resource (oil, steel, among others.) or attracting a labour force that hasn't been exposed to the industry. The last but not the least form is the carrying out of the new organisation of industry that will increase the personal welfare of the entrepreneur (Schumpeter, 1939 and Eshiobo, 2009). For economic development therefore, the technical entrepreneur is a special person of science and technology and commerce who seizes upon, and develops an invention and through his own individual efforts or in conjunction with others, commercially exploits new or adaptive products or novel production techniques and processes. He must combine the skills of the classic entrepreneur with those of research engineers and scientists (Irefin, 2006).

\subsection{Technical Entrepreneurship Development Process}

The highly complex process of new ventures creation is embodied in the entrepreneurship process (Baron, 2004). In general, the entrepreneurship process covers two to five stages. According to Shane (2003), two broad dimensions exist namely: opportunity recognition and resource acquisition. Otero (2000) identifies three distinct stages viz: pre-founding stage, which comprises of opportunity identification and evaluation; a founding stage which involves a business plan, resource gathering, incorporation and market entry; and an early development stage which is establishing the venture and market penetration. 
Also, three stages of the entrepreneurship process are identified by Baron (2004), these include screening ideas for feasibility, gathering required resources and actually developing the venture. On the other hand, four stages are identified by Bygrave (1995) which include opportunity identification, technology set up, organization establishment and exchange. However, Hisrich and Peters (2002) articulate four stages of the entrepreneurial process as opportunity identification and evaluation, business plan preparation, determination of required resources and managing the established venture. Furthermore, the five stages identified by Rwigema and Venter (2004) are identifying, measuring and refining an opportunity from various ideas; preparing a business plan; organizing resources; putting a formidable team together; and overseeing the new venture creation and growth.

\subsection{Statement of the problem}

Despite the efforts by successive government in the development of entreneurship in the country, the impact is yet to be seen in terms of economic development, employment generation, revenue generation among others, the Nigerian entrepreneurs have continued to operate in a very harsh business environment, many agencies established to offer support services according to their mandate notwithstanding. This study was therefore being undertaken to examine the role played by the agencies in providing support service and the impact of the services on the performance of the entrepreneurs

\section{METHODOLOGY}

The research design adopted for this study is the survey method. The South-western zone of the country was selected because it serves as the nation's commercial nerve centre. The high economic activities of the zone are shown by the concentration of institutions providing various aspects of support services to entrepreneurs and the predominance of various types of small, medium and large scale businesses.

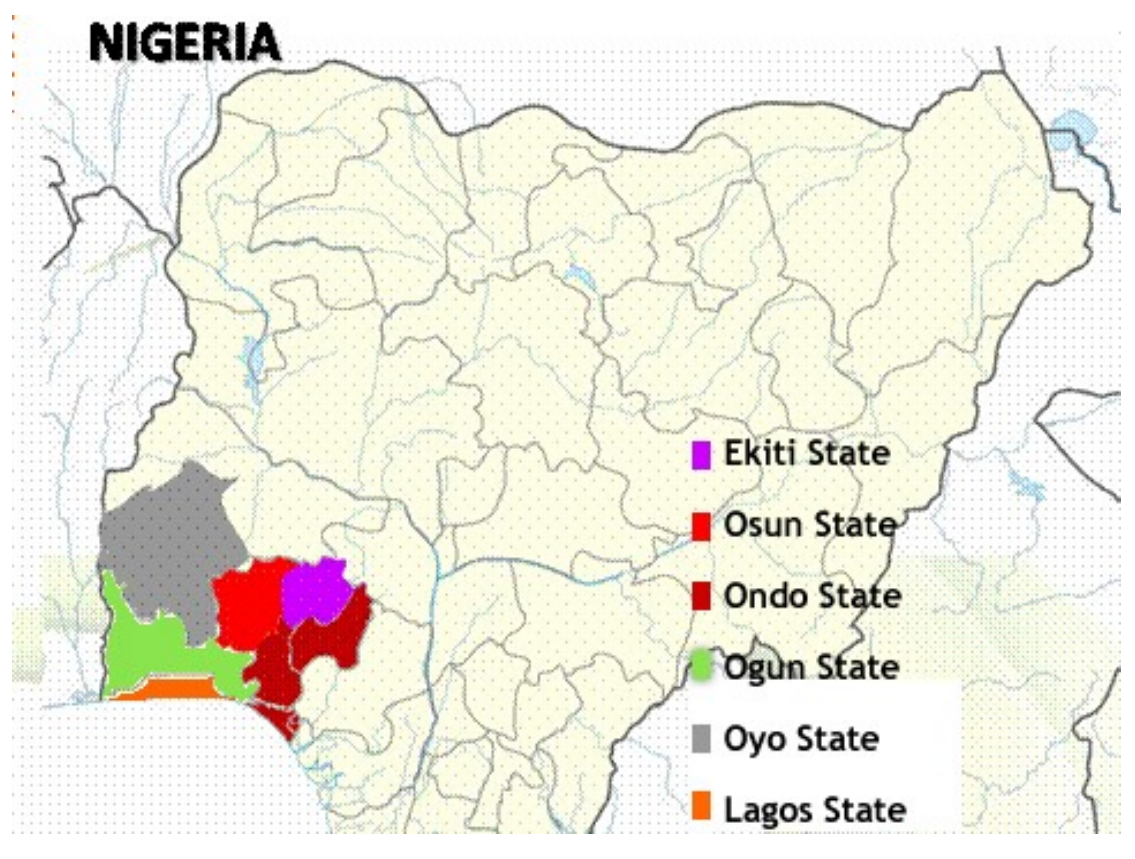

Figure 1: Space Occupied by the South-western Nigeria 
Similarly, the presence of headquarters of national bodies of trade unions and associations also support the choice of the zone as the study area. Examples are National Association of Small and Medium Enterprises (NASME), National Association of Small Scale Industrialists (NASSI), Manufacturers Association of Nigeria (MAN), Lagos Chamber of Commerce and Industry (LCCI) and a host of others. There are many private entrepreneurs with profitable ventures located there. The region is densely populated with a population of about 31,000,000 people according to the 2006 population census (National Population Commission, 2010). It is a politically active zone with all the political parties represented. The states that make up this zone are Ekiti, Lagos, Ogun, Ondo, Osun and Oyo.

\subsection{Study Population and Sampling Technique}

The study population consisted of institutions established to provide one support services or the other to entrepreneurs and the technical entrepreneurs who benefitted from such support services. The institutions considered in the study are Government institutions (Federal and State), Non-governmental organizations, International organizations, Cooperatives societies and Religious organizations (Table 1). The sampling technique employed was multi-stage sampling. The first stage was the selection of the study area, the Southwestern Nigeria, followed by purposive selection of relevant institutions useful for the purpose of the study. Also, the purposive selection of the technical entrepreneurs from the list made available by the institutions. The final stage was the systematic sampling technique which was employed to select the technical entrepreneurs' respondents. From the lists provided by the institutions, after the first element was selected at random every third element was selected at random to ensure the respondents had equal chance of being selected. A total of fourteen institutions supporting entrepreneurship development are in the South-western Nigeria while three hundred and forty-six beneficiaries were systematically sampled.

\section{RESULTS AND DISCUSSIONS}

Table 1 Sources of Beneficiaries/Technical Entrepreneurs

\begin{tabular}{llll}
\hline Institution & $\begin{array}{l}\text { Number of } \\
\text { questionnaire } \\
\text { administered }\end{array}$ & $\begin{array}{l}\text { Number of } \\
\text { questionnaire } \\
\text { retrieved }\end{array}$ & $\begin{array}{l}\text { Percentage response } \\
(\%)\end{array}$ \\
\hline SMEDAN & 32 & 26 & 9.8 \\
NDE & 60 & 52 & 19.7 \\
TIC & 32 & 23 & 8.7 \\
BOI & 25 & 9 & 3.4 \\
FIIRO & 50 & 35 & 13.3 \\
IDC & 23 & 23 & 8.7 \\
IAR\&T & 14 & 9 & 3.4 \\
Cooperative & 15 & 12 & 4.5 \\
MFB & 22 & 20 & 7.6 \\
HDI & 5 & 5 & 1.9 \\
WAPA & 20 & 19 & 7.2 \\
NAPEP & 18 & 13 & 4.9 \\
Mosque & 20 & 13 & 4.9 \\
Church & 10 & 5 & 1.9 \\
Total & 346 & 264 & 100.0 \\
\hline
\end{tabular}

Source: Field Survey and Author's computation, 2018 
Table 2: Socio-demographic characteristics of technical entrepreneur respondents

\begin{tabular}{|c|c|c|c|c|c|c|}
\hline S/No. & & Characteristics & Frequency & Percentage (\%) & Mean & S.D. \\
\hline \multirow[t]{3}{*}{1.} & \multicolumn{6}{|c|}{ Gender } \\
\hline & (a) & Male & 147 & 55.7 & & \\
\hline & (b) & Female & 117 & 44.3 & & \\
\hline \multirow[t]{6}{*}{2.} & \multicolumn{6}{|c|}{ Age (years) } \\
\hline & (a) & $16-30$ & 36 & 13.6 & & \\
\hline & (b) & $31-45$ & 152 & 57.6 & & \\
\hline & (c) & $46-60$ & 66 & 25.0 & & \\
\hline & (d) & $61-75$ & 9 & 3.4 & & \\
\hline & (e) & Above 75 & 1 & 0.4 & 38.57 & 18.74 \\
\hline \multirow[t]{5}{*}{3.} & \multicolumn{6}{|c|}{ Marital status } \\
\hline & (a) & Married & 199 & 75.4 & & \\
\hline & (b) & Single & 55 & 20.8 & & \\
\hline & (c) & Divorced & 3 & 1.1 & & \\
\hline & (d) & Widow & 7 & 2.7 & & \\
\hline \multirow[t]{3}{*}{4 . } & \multicolumn{6}{|c|}{ Nationality } \\
\hline & (a) & Nigerian & 258 & 97.7 & & \\
\hline & (b) & Non-Nigerian & 6 & 2.3 & & \\
\hline \multirow[t]{5}{*}{5.} & \multicolumn{6}{|c|}{ Educational Background } \\
\hline & (a) & Primary School Certificate & 12 & 4.5 & & \\
\hline & (b) & Post Primary School Certificate & 40 & 15.2 & & \\
\hline & (c) & Post-Secondary Certificate & 179 & 67.8 & & \\
\hline & (d) & Higher Degrees & 33 & 12.5 & & \\
\hline \multirow[t]{7}{*}{6.} & \multicolumn{6}{|c|}{ Area of Specialization } \\
\hline & (a) & Pure Science & 45 & 17.0 & & \\
\hline & (b) & Engineering & 49 & 18.6 & & \\
\hline & (c) & Social Sciences & 30 & 11.4 & & \\
\hline & (d) & Management Science & 30 & 11.4 & & \\
\hline & (e) & Humanities & 18 & 6.8 & & \\
\hline & (f) & Vocational and Technical & 92 & 34.8 & & \\
\hline \multirow[t]{5}{*}{7.} & \multicolumn{6}{|c|}{ Position held by respondents } \\
\hline & (a) & MD/CEO/Proprietors & 206 & 78.0 & & \\
\hline & (b) & Director & 28 & 10.6 & & \\
\hline & (c) & Senior Manager & 20 & 7.6 & & \\
\hline & (d) & Production Manager & 10 & 3.8 & & \\
\hline \multirow[t]{6}{*}{8.} & \multicolumn{6}{|c|}{ Years of experience } \\
\hline & (a) & Below 5 years & 108 & 40.9 & & \\
\hline & (b) & $5-10$ & 116 & 43.9 & & \\
\hline & (c) & $11-15$ & 30 & 11.4 & & \\
\hline & (d) & $16-20$ & 0 & 0.0 & & \\
\hline & (e) & $21-25$ & 10 & 3.8 & 8.63 & 4.84 \\
\hline
\end{tabular}

Source: Field Survey, and Author's computation,2018 
In the survey of gender participation in entrepreneurship for this study, the results showed that $55.7 \%$ and 44.3\% were males and females respectively (Table 1). Entrepreneurship can be a cumbersome activity in which entrepreneur has to play multiple roles to achieve success. Many of these roles can be effectively played by males than females who prefer to engage in trading activities rather than production. About $57.6 \%$ of the respondents were in the age group $31-45$, while $13.6 \%, 25.0 \%, 3.4 \%$ and $0.4 \%$ were in the age groups of $16-30$ years, $46-60$ years, $61-75$ years and above 75 years respectively.

The mean age was about 39 years while the standard deviation was 19 years, indicating a wide gap in the ages of the respondents which cut across all age ranges. The result also revealed that those actively engaged in entrepreneurship are within the age bracket 16 and 60 years. It is obvious that at age above 60 years, the strength to engage in business ventures may have been drastically reduced and entrepreneurs above this age may not be able to carry out strenuous business activities. The result further showed that $75.4 \%$ of the entrepreneurs were married, while $20.8 \%, 2.7 \%$, and $1.1 \%$ were singles, widows and divorced respectively. About $97.7 \%$ of the respondents were Nigerians while only $2.3 \%$ were non-Nigerians.

Majority (67.8\%) of the respondents had post-secondary education, 15.2\% had post primary education, $12.5 \%$ had higher degrees while $4.5 \%$ had primary education. The result also showed that $34.8 \%$ specialized in vocational and technical education, $18.6 \%$ in Engineering, $17.0 \%$ in Pure Science, and $11.4 \%$ each in Social and Management Sciences. Most (78.0\%) of the respondents were owners of the businesses, 10.6\% were directors, $7.6 \%$ were senior managers and $3.8 \%$ were production managers.

The result showed that all the respondents were literates and that the elites are now engaged in business ventures. Years of experience of respondents revealed that $43.9 \%$ had been in business within 5 - 10 years, 40.9\% had below 5 years of experience while $11.4 \%$ and $3.8 \%$ had between 11 and 15 years, and 21 and 25 years of experience respectively. The mean of the years of experience was about 9 years while the standard deviation was 5 years

\subsection{Technical entrepreneurs' performance variables}

The technical entrepreneurs' performance variables include production activities and marketing operations and the impact of support services received on production activities, were considered using the following parameters: production output, sales turnover, profitability, staff strength, product registration, reduction in operational and maintenance costs and product quality. These variables were measured using 5 point Likert scale of 1 for very low and 5 for very high and Analysis of Variance Test (ANOVA) was conducted to test the significance of the support services on the performance of the entrepreneurs. 
Table 3: Impact of the support services on the performance of entrepreneurs

\begin{tabular}{lllll}
\hline S/No. & Parameters of performance & Mean square & F value & P value \\
\hline
\end{tabular}

1. Technical

$\begin{array}{lllll}\text { (a } & \text { Production output } & 0.7821 & 3.74 & 0.001{ }^{\circ} \\ \text { (b } & \text { Sales turnover } & 0.6268 & 3.00 & 0.020 \\ \text { (c } & \text { Profitability } & 0.47795 & 2.28 & 0.06 \\ \text { (d } & \text { Staff strength } & 0.45398 & 2.17 & 0.07 \\ \text { (e) } & \text { Product registration } & 0.0338 & 0.16 & 0.9974 \\ \text { (f) } & \text { Reduction in operating cost } & 0.312 & 1.49 & 0.2087 \\ \text { (g } & \text { Reduction in maintenance cost } & 0.086 & 0.41 & 0.7993 \\ \text { (h } & \text { Product quality } & 0.0922 & 0.44 & 0.77\end{array}$

2. Financial

$\begin{array}{lllll}\text { (a } & \text { Production output } & 0.628 & 2.92 & 0.0071 \\ \text { (b } & \text { Sales turnover } & 0.5451 & 2.53 & 0.0433 \\ \text { (c } & \text { Profitability } & 0.4473 & 2.08 & 0.087 \\ \text { (d } & \text { Staff strength } & 0.3959 & 1.84 & 0.1252 \\ \text { (e } & \text { Product registration } & 0.0292 & 0.14 & 0.9689 \\ \text { (f) } & \text { Reduction in operating cost } & 0.31397 & 1.46 & 0.21087 \\ \text { (g } & \text { Reduction in maintenance cost } & 0.1784 & 0.83 & 0.5093 \\ \text { (h } & \text { Product quality } & 0.1066 & 0.50 & 0.7393\end{array}$

3. Information

$\begin{array}{lllll}\text { (a } & \text { Production output } & 0.24175 & 1.46 & 0.1830 \\ \text { (b } & \text { Sales turnover } & 0.09649 & 0.58 & 0.6742 \\ \text { (c } & \text { Profitability } & 0.30751 & 1.86 & 0.1205 \\ \text { (d } & \text { Staff strength } & 0.14168 & 0.86 & 0.4907 \\ \text { (e } & \text { Product registration } & 0.46263 & 2.80 & 0.283 \\ \text { (f) } & \text { Reduction in operating cost } & 0.25700 & 1.56 & 0.1893 \\ \text { (g } & \text { Reduction in maintenance cost } & 0.424923 & 2.58 & 0.0405 \\ \text { (h } & \text { Product quality } & 0.55608 & 3.37 & 0.0116\end{array}$

4. Human resource development

\begin{tabular}{|c|c|c|c|c|}
\hline (a & Production output & 0.14371 & 0.87 & 0.5332 \\
\hline$(b$ & Sales turnover & 0.30396 & 1.84 & 0.1253 \\
\hline (c & Profitability & 0.44349 & 2.68 & 0.0343 \\
\hline$(d$ & Staff strength & 0.3849 & 2.33 & 0.0595 \\
\hline (e & Product registration & 0.09769 & 0.59 & 0.6701 \\
\hline (f) & Reduction in operating cost & 0.185305 & 1.12 & 0.3498 \\
\hline$(g$ & Reduction in maintenance cost & 0.18119 & 1.10 & 0.3616 \\
\hline$(\mathrm{h}$ & Product quality & 0.93401 & 5.65 & $0.003^{\circ}$ \\
\hline
\end{tabular}

5. General

\begin{tabular}{lllll} 
(a & Production output & 0.15529 & 1.09 & 0.3736 \\
(b & Sales turnover & 0.07132 & 0.50 & 0.7355 \\
(c & Profitability & 0.24313 & 1.71 & 0.1524 \\
(d & Staff strength & 0.01350 & 0.09 & 0.9840 \\
(e & Product registration & 0.12310 & 0.86 & 0.4877 \\
(f) & Reduction in operating cost & 0.12559 & 0.88 & 0.4772 \\
(g & Reduction in maintenance cost & 0.23216 & 1.63 & 0.1707 \\
(h & Product quality & 0.03885 & 0.27 & 0.8952 \\
\hline
\end{tabular}

Source: Field Survey and author's computation,2018 
It is expected that entrepreneurs utilize support services received to the advantage of their enterprises. The results showed that support servcies' impact on the performance of the technical entrepreneurs was significant. Using multivariate analysis, the result showed that the impact of the technical support services on production output $(\mathrm{F}=3.74, \mathrm{p}<0.05)$, sales turnover $(\mathrm{F}=3.00, \mathrm{p}<0.05)$ were positive and significant at $5 \%$ level. This indicates that 5 units increase in the provision of technical support services would improve production output and sales turnover and also implies that production output and sales turnover are the first major and evident results of the receipt of any type of technical support services. Hence, technical support service is core to increased production output and sales turnover as previously claimed by Adegbite (1995), Egesi (2004) and Coleman (2015). The result also showed that the impact of financial support services was positive and significant on production output and sales turnover at 5\% level of significance. The results corroborate the claim of Bato (2006) and Saleh (2004) that financial support to entrepreneurs would enable them realize their desire of quality product, reliability and competitiveness. The result revealed that information support services had a positive impact on product quality and reduction in maintenance costs implying that correct information received by an entrepreneur and rightly applied could enhance business operations.

Similarly, human resource development support services had positive and significant effect on product quality $(\mathrm{F}=5.65, \mathrm{p}=0.003)$ and profitability $(\mathrm{F}=2.68, \mathrm{p}=0.0343)$ while the impact on staff strength was at $10 \%$ level of significance. This implies that capacity building for the staff would impact on the quality of product turned out by the venture or service as a result of the enhanced knowledge. The positive impact in product quality will enhance sales and thereby result in profitability which is the ultimate desire of the entrepreneurs (Egesi, 2004).

\section{CONCLUSION}

The level of interest in entrepreneurship by female and youths is generally increasing. This could be as a result of job scarcity and that men can no longer bear domestic responsibilities alone. It is heartwarming to acknowledge that the institutions provided support services to technical entrepreneurs in the south- western Nigeria. The support services received significantly impacted production output, sales turnover, reduction in maintenance costs, product quality and profitability. The more the support services received by technical entrepreneurs the more the quality of the contribution of the sector to the economic development of the nation.

\section{RECOMMENDATIONS}

Following the findings of the study, it is recommended that the support services should be easily and timely accessed by entrepreneurs. Government should encourage synergy among the support services institutions to facilitate a single window opportunity for entrepreneurs to access all the support services. It is also important to strengthen institutions through adequate funding to enable these institutions provide these services with ease for the development of the sector and ultimately the economic development of the country. 


\section{REFERENCES}

1. Eshiobo, M. (2009). Entrepreneurshp in Innovation, Phenomena, Growth of Enterprise and Industrial Organisation in Nigeria, pp. 5-18.

2. Ilori, M. O. (2010). "Technical entrepreneurship development," paper presented at the Yaba College of Technology, Yaba, Lagos, pp. 1-2.

3. Schumpeter, J. (1939). "Business Cycles: A Theoretical, Historical, and Statistical Analysis of the Capitalist Process” New York's and London MCgraw-Hill.

4. Adegbite, O. (1995). "The role of technology in incubation centres in entrepreneurship development.” Journal of Management, 3(2): 72-80.

5. Baron, R.C. (2004). "Potential benefits of cognitive perspective: expanding entrepreneurship's array of conceptual tools.” Journal of Business Venturing, 19, pp 169-172.

6. Bato, D. (2006). Entrepreneurship Development: Concept and Content: A publication of Maharasha Economic Development Council in India, pp. 450-470.

7. Bygrave, W.D. (1995). "Theory building in the entrepreneurship paradigm.” Journal of Business Venturing, 8:255-280.

8. Coleman, S. (2015). Acess to Capital and Terms of Credits: A Comparison of Men and Women Owned Small Business Journal of Small Business Management, 36(3):37-52

9. Egesi, G.U. (2004). "Marketing Strategies for Small Scale Businesses" in D. Okongwu and A. Saleh, (eds.), Fundamental Issues in Entrepreneurship, Yaba, Lagos, Apex Books Limited, pp155180 .

10. Eshiobo, M. (2009), Entrepreneurship in Innovation, Phenomena, Growth of Enterprise and Industrial Organisation in Nigeria, pp. 5-18.

11. Histrich, R.D and Peters, M.P. (2002). " Entrepreneurship in Singapore”, Mcgraw-Hill, p.

12. Ilori, M.O (2010). "Technical entrepreneurship development," paper presented at Yaba College of Technology, Yaba, Lagos, pp. 1-2.

13. Olatunji, O. (2010). Entrepreneurship skills: a viable option in the face of employment challenges of new generation of Nigeria. Paper presented at Yaba College of Technology, Yaba, Lagos, September 17, pp. 8-10.

14. Otero, M. (2000). "Bringing development back into microfinance," ACCION International.

15. Ronstadt, R (1996). This corridor of principle, Journal of Business Venturing, 3 (4), 31-40.

16. Rwigema, H. And Venter R. (2004). "Advanced Entrepreneurship in Cape Town” Oxford University Press.

17. Say, J.B (1824) . 'A Treatise on Political Economic Principles, C.K. Trans 4th edition Well and Lily,' Boston M.A. U.S.A

18. Schoof, U. (2006).' Stimulating Youth Entrepreneurship; Barriers and Incentives', pp 221- 250.

19. Schumpeter, J. (1939). "Business Cycles: A Theoretical, Historical, and Statistical Analysis of the Capitalist Process” New York's and London McGraw-Hill.

20. Shane, S. (2003). "A general theory of entrepreneurship: The individual-opportunity Nexus. Massachusetts: Edward Eglar Publishing Inc.

21. Ubom, E. (2003). "Entrepreneurship, Small and Medium Enterprises: Theory, Practice and Policies" Lagos, Nigeria: Sendina Publisher.

22. Wood, J. S (2005) 'The Development and present state of the Theory of Entrepreneurship , in Product and Asset Markets', pp7-10 